\title{
Gender Differences Specially in health: A Case Study in Meghalaya and Tripura
}

\author{
Bhola Nath Ghosh \\ Assistant Professor Sociological Research Unit Indian Statistical Institute 203, B.T. Road Kolkata -700 108
}

\begin{abstract}
Male and female are like two sides of the same coin. The development of science and the society is due to the combined effort of male \& female members in the society. But in actual practice they are not treated equally. In the patrilineal societies, women are not considered as equal with men, though they enjoy a better social status than men. In patrilineal societies a women, after the marriage, leave her natal place permanently and goes to reside with her husband. Again, in patrilineal societies the ritual role of the male is considered more vital than the female. These being the most influential reasons, the women have remained backward in various fields as compared to males. In some traditional societies, they are considered as social and economic burden on the parents and hence some of the parents do not prefer to have female issues. We will discuss different issues but emphasis will be given on health.

Two states in North-East India namely Meghalaya \& Tripura have been chosen for investigation. Meghalaya is dominated by tribes who belong to matrilineal societies, whereas Tripura is almost completely patrilineal. We have investigated the gender differences in these two states.
\end{abstract}

Keywords: Patrilineal Societies, Matrilineal Societies, Social Status, Gender Differences, Health

\section{Introduction:}

The Indian constitution recognizes the equality of sexes. During the past fifty nine years of independence, due to socio-economic welfare and developmental activities in several spheres of society, there has been changes in the status of women and on their equal role and importance in every walk of life. But this may be true and confined mainly to urban society.

Discrimination across gender is the most distressing fact as such discrimination cuts across caste, class and ethnic composition. The gender discrimination is present in almost all societies, whether feudal or capitalist. Abolition of the evil of social inequality is an important but an uphill task. Due to the combined effort of all those concerned at the academic, social and welfare levels and all development activities in education, awareness programmes the social inequalities has narrowed down to a certain extent when compare it to the previous state of the society (Beteille, 1974). Where social inequality prevails, both men and women become victims of it. But it is an irony of state that it is the women as collectively who are most victimized and discriminated in most of the cases.

In many societies, especially in rural areas, women take the responsibility of fetching drinking water, collecting fuel wood as well as take part in gardening and agricultural activities from sowing to harvesting. Their role either as a mother or as a wife in addition to other socio-economic performances has immense importance in the welfare of the society. Sometimes being in very poor (low-income) families they themselves sustain without sufficient food or nutritional intake but try hard to fulfill the nutritional need of their male members in their family. Whereas, in most cases, because of the lack of recognition and due to the nonmarketing nature of works, proper evaluation of these activities by women have never been made. Their contribution to the society is however no less than their counterpart. Even some researchers and famous sociologists thought that women's role in traditional societies are more comprehensive, active, independent and valued (Hamilton, 1981; Schreiner, 1978).

Despite their important contribution to the society, in earlier days they were not allowed to take part in decision making. Even in the traditional societies (like that of many tribal societies in North-East India), where females control the most economic activities, women are not allowed to take part in Darbars or village council meeting. There, the headman of a cluster of population is a man and thus major decisions are taken by men.

Historical evidence shows that in very early stages of our society, women were regarded like mother, goddess (Shakti) - a symbol of life with immense capacity of tolerance and sacrifice and hence they had a respectful place in the society (Menon, 1975). In ancient Rig Vedic period, they were the co-partners in life, in all pleasures and hazards, enjoying the joys and tolerating sorrows together (Thomas, 1964).

Ghosh and De (2005) have shown that if the woman member in Panchayat or as Panchayat Prodhan is educated and have the independent decision making capability than the performance is bound to improve. It is accepted that the women in general are less corrupted. Chattopadhyay and Dufflo (2001) have also explained the impact of having women in panchayat administration either as member or prodhan. From the result of their 
primary survey, they found that the panchayat having women prodhan give emphasis more on infrastructure development, adult education and building education infrastructure. Also they stress more on women issues like health care for mother and children, problem of nutrition in the panchayat meeting.

Devendra (1993) has shown that the only time when a woman received respect and care from her family when she becomes the mother of a son.

Madhu Kishwar (1996) argues that a present scheme of reservation will "ghettoize" women's politics confining them to contesting only from the reserved constituencies. She further maintains that the lottery system of gender-based reservation would inhibit women from nursing their constituency, which could damage the legitimacy of women's participation.

Choksi (1995) believed that advancing gender equality; governments could greatly enhance the future well-being and prosperity of their people. But no such effort can however be successful without the participation of women themselves (World Bank, 1995).

Discrimination across gender is the most distressing fact as such discrimination cuts across caste, class and ethnic composition (De Haan, 1994).

\section{Area of the Study and the Findings}

The gender discrimination is present in all societies, whether feudal or capitalist. But the form of the discrimination is different at different places. Thus to have a comprehensive idea about the different forms of discrimination, it is necessary to undertake in-depth studies at various places of a given region. Towards this end, we have selected two states of northeastern region - one state being the one where the $73^{\text {rd }}$ amendment has not yet been implemented (Meghalaya) and another state is the one where the above amendment has been implemented (Tripura). The villages from each of the states have been purposively selected. In Tripura, these villages are Betelli and Kalitila of Paschim Noabadi Gram Panchayat under Jirania block, West Tripura district and in Meghalaya; the villages are Ringikseh and Kynton-u-mon under East Khasi Hill district of Mawlyngknang block.

Exhaustive listing of the households in all the four selected villages have been made taking note of the main characteristics of the heads of the households such as marital status, earnings and expenditures, literacy status, occupation etc. and some particulars of the households which include family size, whether belongs to BPL category etc.

Table 1 gives the summary of the heads of households in the four villages. Altogether 587 households were listed of which 330 households were in Tripura and 257 were in Meghalaya. Among the 587 households, only 148 have female as head of the households.

An in-depth study was made by taking a subset of these households randomly ${ }^{1}$. We shall however report the results on the basis of data collected using the listing schedule only. Firstly, because it avoids sampling errors. Secondly, it also tries to minimize non-sampling errors to some extent, because only summary information is sought.

Table 1: Distribution of households by sex of head of the households

\begin{tabular}{|l|l|c|c|c|}
\hline \multirow{2}{*}{ State } & \multirow{2}{*}{ Village } & \multicolumn{2}{|c|}{ Sex } & \multirow{2}{*}{ Total } \\
\cline { 3 - 4 } & & Male & Female & \\
\hline \multirow{4}{*}{ Tripura } & Beltali & $110(80,29)$ & $27(19,71)$ & $137(\mathbf{2 3 , 3 4})$ \\
\cline { 2 - 4 } & Kalitila & $154(79,79)$ & $39(20,21)$ & $193(\mathbf{3 2 , 8 8})$ \\
\cline { 2 - 4 } & Total & $264(80)$ & $66(20)$ & $\mathbf{3 3 0}(\mathbf{5 6 , 2 2})$ \\
\hline \multirow{5}{*}{ Meghalaya } & Kyton-u-mon & $102(73,91)$ & $36(26,09)$ & $138(\mathbf{2 3 , 5 1})$ \\
\cline { 2 - 4 } & & & $46(38,6)$ & $119(\mathbf{2 0 , 2 7})$ \\
\cline { 2 - 4 } & Ringkseh & $73(61,34)$ & $46(31,91)$ & $257(\mathbf{4 3 , 7 8})$ \\
\cline { 2 - 4 } & Total & $175(68,09)$ & 148 & 587 \\
\hline \multicolumn{2}{|c|}{ Grand Total } & 439 & & \\
\hline
\end{tabular}

Figures in parentheses give percentages.

\footnotetext{
${ }^{1}$ Using Stratified Random Sampling 35 male headed households out of 110 and 20 female headed households out of 27 in Beltali, are selected and 35 male headed households out of 154 and 20 female headed households uot of 39 have been selected in Kalitila. For Meghalaya from the village Ringseh 25 male headed households out of 73 and 20 female headed households out of 46have been chosen randomly, whereas in Kyton-u-mon 30 male headed households out of 102 and 20 female headed households out of 36 have been chosen randomly.
} 
From Table 1 it is seen that the ratio of male heads to female heads is almost 4:1 in all the villages of Tripura, but in Meghalaya where the society is matrilineal the ratio in of the village Kyton-u-mon is 3:1 and in the other village Ringkseh, it is only 1.6:1. Thus the overall ratio in Meghayalaya is approximately 2:1.

Marital Status:

According to the figures in Table 2, we can see that in the male-headed households the 'married once' characteristic dominates over all the other characteristics, which are ' unmarried', 'married more than once', ' widow', and 'divorced', but in the female headed households the 'widow' and the 'divorced' characteristics dominate. It clearly shows how male members dominate. A female member becomes head of the household only when she is forced to become head.

Though there is a provision of marrying more than once in the Khasi community among the women none were found to do so.

Table: 2 Distribution of households by marital status

\begin{tabular}{|r|c|c|c|c|c|c|c|}
\hline State & Sex & \multicolumn{5}{|c|}{ Marital status } & \multirow{2}{*}{ Subtotal } \\
\cline { 3 - 8 } & & Unmarried & $\begin{array}{c}\text { Married } \\
\text { once }\end{array}$ & $\begin{array}{c}\text { Married } \\
\text { more than } \\
\text { once }\end{array}$ & Widow & Divorced & \\
\hline Tripura & Male & $3(1,14)$ & $\begin{array}{c}254 \\
(96.21)\end{array}$ & $3(1.14)$ & $3(1.14)$ & $1(0.38)$ & $\begin{array}{c}264 \\
(80.00)\end{array}$ \\
\cline { 2 - 8 } & Female & $2(3,03)$ & $8(12.12)$ & 0 & $52(78.79)$ & $4(6.06)$ & $\begin{array}{c}66 \\
(20.00)\end{array}$ \\
\hline Meghalaya & Male & $6(3,43)$ & $\begin{array}{c}160 \\
(91.43)\end{array}$ & 0 & $4(2.29)$ & $5(2.86)$ & $\begin{array}{c}175 \\
(68.09)\end{array}$ \\
\cline { 2 - 8 } & Female & $3(3,66)$ & $15(18.29)$ & 0 & $37(45.12)$ & $27(32.93)$ & $\begin{array}{c}82 \\
(31.91)\end{array}$ \\
\hline
\end{tabular}

Figures in parentheses give percentages.

\section{Earning Status:}

In both the states the males are mostly earners. In Tripura we can find 3.79\% of the total male-headed households' heads are dependent. In Meghalaya our survey reveals that none of the male heads are dependent.

In Tripura the earner dependent ratio of the female heads is 1:1 (total) but in Meghalaya it is almost equal to 2:1 (total).

The figure of Table- 3 shows that everywhere and in every respect the heads of the families are earners with a slight exception in the case of the females of the village Kalitila in Tripura, where there are more dependent heads than the earner heads of the households. than females.

Earning status is one of the main factors, which lead to empowerment. Males are thus more empowered

Table 3: Distribution of the households by earning status

\begin{tabular}{|c|c|c|c|c|}
\hline State & Sex & \multicolumn{2}{|c|}{ Earner/Dependent } & Subtotal \\
\hline & & Dependent & Earner & \\
\hline Tripura & Male & $10(3.79)$ & $254(96.21)$ & $264(\mathbf{8 0 . 0 0})$ \\
\hline & Female & $33(50.00)$ & $33(50.00)$ & $66(\mathbf{2 0 . 0 0})$ \\
\hline Meghalaya & Male & $0(0.00)$ & $175(100.00)$ & $175(\mathbf{6 8 . 0 9})$ \\
\hline & Female & $27(32.93)$ & $55(67.07)$ & $82(\mathbf{3 1 . 9 1})$ \\
\hline
\end{tabular}

Figures in parentheses give percentages.

\section{Literacy Status:}

Among females there are $60.6 \%$ illiterates in Tripura and $63.4 \%$ illiterates in Meghalaya. These percentages are quite high. It is higher than the all India figure. Among males the situation is much improved. There are only $13.3 \%$ males in Tripura who are illiterate. But in Meghalaya it is about $55 \%$. The percentage of illiterates in Tripura and Meghalaya are 22.5 and 57.6 respectively. This is possibly not the representative picture of Tripura and Meghalaya. 


\begin{tabular}{|c|c|c|c|c|}
\hline \multirow{2}{*}{ State } & \multirow{2}{*}{ Sex } & \multicolumn{2}{|c|}{ Literacy status } & \multirow{2}{*}{ Subtotal } \\
\cline { 3 - 4 } & & Illiterate & Literate & \\
\hline \multirow{2}{*}{ Tripura } & Male & $35(13.3)$ & $229(86.7)$ & $264(\mathbf{8 0})$ \\
\cline { 2 - 4 } & Female & $40(60.6)$ & $26(26)$ & $66(\mathbf{2 0})$ \\
\hline \multirow{2}{*}{ Meghalaya } & Male & $96(54.9)$ & $79(45.1)$ & $175(\mathbf{6 8 . 1})$ \\
\cline { 2 - 4 } & Female & $52(63.4)$ & $30(36.6)$ & $82(\mathbf{3 1 . 9})$ \\
\hline
\end{tabular}

Figures in parentheses give percentages.

\section{Monthly Expenditure:}

In comparison with respect to the gender, female heads are more in the BPL category than their male counterparts in Tripura, but this discrepancy is less in Meghalaya, where in BPL status the male and female heads are equal.

But if we see the group having monthly household expenditure more than Rs. 5000 we can see that $4.17 \%$ of the total male heads and $7.58 \%$ of the total female heads are in this group in the villages of Tripura, whereas none can be found in this group for Maghalaya irrespective of their gender. The grand total reveals that almost $30 \%$ and $45 \%$ of the total male and female heads respectively belong to the BPL category ${ }^{2}$.

Table 5: Distribution of the households by their monthly expenditures

\begin{tabular}{|c|c|c|c|c|c|c|c|c|c|}
\hline \multirow{2}{*}{$\frac{\text { State }}{(1)}$} & Village & Sex & \multicolumn{5}{|c|}{ Monthly Expenditure Groups } & \multirow{3}{*}{$\begin{array}{c}\text { Subtotal } \\
(6)\end{array}$} & Total \\
\hline & \multirow{2}{*}{$(2)$} & \multirow[t]{2}{*}{ (3) } & \multicolumn{5}{|c|}{$(4)$} & & $(7)$ \\
\hline & & & $<1499$ & $\begin{array}{l}1500- \\
2500\end{array}$ & $\begin{array}{l}2501- \\
4000\end{array}$ & $\begin{array}{c}4001- \\
5000\end{array}$ & $>5000$ & & \\
\hline \multirow{6}{*}{ Tripura } & \multirow[b]{2}{*}{ Beltali } & Male & $\begin{array}{r}7 \\
(6,36)\end{array}$ & $\begin{array}{r}52 \\
(47,27)\end{array}$ & $\begin{array}{r}46 \\
(41,82)\end{array}$ & $\begin{array}{r}2 \\
(1,82)\end{array}$ & $\begin{array}{r}3 \\
(2,73)\end{array}$ & $\begin{array}{r}110 \\
(80,29)\end{array}$ & \multirow[t]{2}{*}{$\begin{array}{r}137 \\
(23,3)\end{array}$} \\
\hline & & Female & $\begin{array}{r}4 \\
(14,81) \\
\end{array}$ & $\begin{array}{r}14 \\
(51,85) \\
\end{array}$ & $6(22,22)$ & $\begin{array}{r}1 \\
(3,70) \\
\end{array}$ & $\begin{array}{r}2 \\
(7,41) \\
\end{array}$ & $\begin{array}{r}27 \\
(19,71) \\
\end{array}$ & \\
\hline & \multirow[t]{2}{*}{ Kalitila } & Male & $\begin{array}{r}3 \\
(1,95)\end{array}$ & $\begin{array}{r}59 \\
(38,31)\end{array}$ & $\begin{array}{r}63 \\
(40,91)\end{array}$ & $\begin{array}{r}21 \\
(13,64)\end{array}$ & $\begin{array}{r}8 \\
(5,19)\end{array}$ & $\begin{array}{r}154 \\
(79,79)\end{array}$ & \multirow[t]{2}{*}{$\begin{array}{r}193 \\
(32,9)\end{array}$} \\
\hline & & Female & $\begin{array}{r}6 \\
(15,38)\end{array}$ & $\begin{array}{r}6 \\
(15,38)\end{array}$ & $\begin{array}{r}20 \\
51,28)\end{array}$ & $\begin{array}{r}4 \\
(10,26)\end{array}$ & $\begin{array}{r}3 \\
(7,69)\end{array}$ & $\begin{array}{r}39 \\
(20,21)\end{array}$ & \\
\hline & \multirow[t]{2}{*}{ Total } & Male & $\begin{array}{r}10 \\
(3,79)\end{array}$ & $\begin{array}{r}111 \\
(42,05) \\
\end{array}$ & $\begin{array}{r}109 \\
(41,29) \\
\end{array}$ & $\begin{array}{r}23 \\
(8,71) \\
\end{array}$ & $\begin{array}{r}11 \\
(4,17)\end{array}$ & $\begin{array}{r}264 \\
(80,00)\end{array}$ & \multirow[t]{2}{*}{$\begin{array}{r}330 \\
(56,2)\end{array}$} \\
\hline & & Female & $\begin{array}{r}10 \\
(15,15)\end{array}$ & $\begin{array}{r}20 \\
(30,30)\end{array}$ & $\begin{array}{r}26 \\
(39,39)\end{array}$ & $\begin{array}{r}5 \\
(7,58)\end{array}$ & $\begin{array}{r}5 \\
(7,54)\end{array}$ & $\begin{array}{r}66 \\
(20,00)\end{array}$ & \\
\hline \multirow{6}{*}{ Meghalaya } & \multirow{2}{*}{$\begin{array}{l}\text { Kyton-u- } \\
\text { mon }\end{array}$} & Male & $\begin{array}{r}78 \\
(76,47)\end{array}$ & $\begin{array}{r}14 \\
(13,73)\end{array}$ & $\begin{array}{r}10 \\
(9,80)\end{array}$ & 0 & 0 & $\begin{array}{r}102 \\
(73,91)\end{array}$ & \multirow[t]{2}{*}{$\begin{array}{r}138 \\
(23,5)\end{array}$} \\
\hline & & Female & $\begin{array}{r}27 \\
(75,00)\end{array}$ & $\begin{array}{r}7 \\
(19,44) \\
\end{array}$ & $\begin{array}{r}2 \\
(5,56)\end{array}$ & 0 & 0 & $\begin{array}{r}36 \\
(26,09)\end{array}$ & \\
\hline & \multirow[t]{2}{*}{ Ringkseh } & Male & $\begin{array}{r}44 \\
(60,27) \\
\end{array}$ & $\begin{array}{r}4 \\
(5,48)\end{array}$ & $\begin{array}{r}25 \\
(34,25) \\
\end{array}$ & 0 & 0 & $\begin{array}{r}73 \\
(61,34) \\
\end{array}$ & \multirow[t]{2}{*}{$\begin{array}{r}119 \\
(20,3)\end{array}$} \\
\hline & & Female & $\begin{array}{r}30 \\
(65,22) \\
\end{array}$ & $\begin{array}{r}3 \\
(6,52) \\
\end{array}$ & $\begin{array}{r}13 \\
(28,26) \\
\end{array}$ & 0 & 0 & $\begin{array}{r}46 \\
(38,66) \\
\end{array}$ & \\
\hline & \multirow[t]{2}{*}{ Total } & Male & $\begin{array}{r}122 \\
(69,71) \\
\end{array}$ & $\begin{array}{r}18 \\
(10,29) \\
\end{array}$ & $\begin{array}{r}35 \\
(20,00) \\
\end{array}$ & 0 & 0 & $\begin{array}{r}175 \\
(68,09) \\
\end{array}$ & \multirow[t]{2}{*}{$\begin{array}{r}257 \\
(43,8)\end{array}$} \\
\hline & & Female & $\begin{array}{r}57 \\
(69,51) \\
\end{array}$ & $\begin{array}{r}10 \\
(12,20) \\
\end{array}$ & $\begin{array}{r}15 \\
(18,29) \\
\end{array}$ & 0 & 0 & $\begin{array}{r}82 \\
(31,91) \\
\end{array}$ & \\
\hline \multirow{2}{*}{\multicolumn{2}{|c|}{ Grand Total }} & Male & $\begin{array}{r}132 \\
(30,07)\end{array}$ & $\begin{array}{r}129 \\
(29,38)\end{array}$ & $\begin{array}{r}144 \\
(32,80)\end{array}$ & $\begin{array}{r}23 \\
(5,24)\end{array}$ & $\begin{array}{r}11 \\
(2,51)\end{array}$ & $\begin{array}{r}439 \\
(74,79)\end{array}$ & \multirow[t]{2}{*}{$\begin{array}{r}587 \\
(100)\end{array}$} \\
\hline & & Female & $\begin{array}{r}67 \\
(45,27)\end{array}$ & $\begin{array}{r}30 \\
(20,27)\end{array}$ & $\begin{array}{r}41 \\
(27,70)\end{array}$ & $\begin{array}{r}5 \\
(3,38)\end{array}$ & $\begin{array}{r}5 \\
(3,38)\end{array}$ & $\begin{array}{r}148 \\
\left(25,21^{\prime}\right)\end{array}$ & \\
\hline & & Total & $\begin{array}{r}19 \\
(33,9\end{array}$ & $\begin{array}{r}15 \\
(27,0\end{array}$ & \begin{tabular}{l|r}
9 & 18 \\
) & $(31,5$
\end{tabular} & $\begin{array}{r}2 \\
(4,77\end{array}$ & $(2,7$ & $(100$ & \\
\hline
\end{tabular}

Figures in parentheses give percentages.

\section{Participation in outside Activities :}

${ }^{2}$ Here it should be mentioned that it is more appropriate to take monthly per capita expenditures of the households for comparison. But the results would almost be same in this case if we take so. 
In Meghalaya 91.43\% male and 93\% female heads of the male headed and female headed households have no participation in outside activities. In Tripura 54\% male and $66.66 \%$ female heads of the male headed and female headed households have no participation in outside activities.

The main dominating outside activities in Tripura is 'visiting panchayat' . There are almost $46.36 \%$ of the total male heads and $22.22 \%$ of the total female heads in Beltali of Tripura who visit the gram panchayat, the percentages for the category in Kalitila is 34.24 among the total male heads and 13.20 among the total female heads.

The prevailing mode of participation in outside activities for the female groups in Meghalaya is going to club but it is only seen in the village Ringkseh.

Table 6: Distribution of the head of the households by their participation in the outside activities

\begin{tabular}{|c|c|c|c|c|c|c|c|c|c|c|c|c|c|c|c|c|c|c|c|}
\hline \multirow[b]{2}{*}{ State } & \multirow[b]{2}{*}{ Village } & \multirow[b]{2}{*}{$\begin{array}{l}\mathrm{Se} \\
\mathrm{x}\end{array}$} & \multicolumn{15}{|c|}{ Participation } & \multirow[b]{2}{*}{ 貝貝 } & \multirow{2}{*}{$\begin{array}{l}\text { Tot } \\
\text { al }\end{array}$} \\
\hline & & & $\stackrel{\mathscr{0}}{\circ}$ & $\begin{array}{l}\frac{x}{0} \\
\frac{x}{3} \\
\frac{0}{0} \\
\frac{0}{x}\end{array}$ & $\frac{0}{3}$ & 言 & 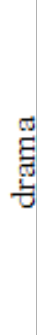 & 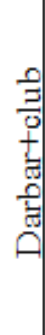 & 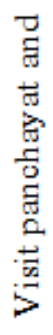 & 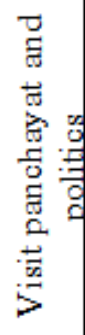 & 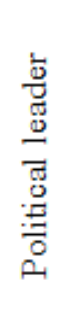 & 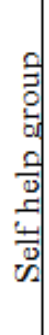 & 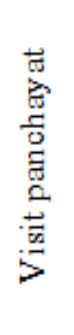 & 足 & 营 & 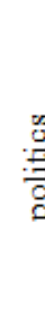 & & & \\
\hline \multirow[t]{6}{*}{ Tripura } & \multirow[t]{2}{*}{ Beltali } & $\mathrm{M}$ & 52 & 0 & 1 & 0 & 0 & 0 & 1 & 2 & 0 & 0 & 51 & 0 & 0 & 2 & 1 & 110 & 137 \\
\hline & & F & 16 & 0 & 0 & 0 & 0 & 0 & 0 & 3 & 0 & 1 & 6 & 0 & 0 & 0 & 1 & 27 & \\
\hline & \multirow[t]{2}{*}{ Kalitila } & $\mathrm{M}$ & 90 & 0 & 1 & 0 & 0 & 0 & 1 & 3 & 3 & 1 & 53 & 0 & 1 & 1 & 0 & 154 & \multirow[t]{2}{*}{193} \\
\hline & & $\mathrm{F}$ & 28 & 1 & 0 & 0 & 0 & 0 & 0 & 1 & 0 & 1 & 7 & 1 & 0 & 0 & 0 & 39 & \\
\hline & \multirow[t]{2}{*}{ Total } & $\mathrm{M}$ & 142 & 0 & 2 & 0 & 0 & 0 & 2 & 5 & 3 & 1 & 104 & 0 & 1 & 3 & 1 & 264 & \multirow[t]{2}{*}{330} \\
\hline & & $\mathrm{F}$ & 44 & 1 & 0 & 0 & 0 & 0 & 0 & 4 & 0 & 2 & 13 & 1 & 0 & 0 & 1 & 66 & \\
\hline \multirow{6}{*}{$\begin{array}{l}\text { Megha } \\
\text { laya }\end{array}$} & \multirow{2}{*}{$\begin{array}{l}\text { Kyton- } \\
\text { u-mon }\end{array}$} & $\mathrm{M}$ & 97 & 0 & 1 & 1 & 0 & 3 & 0 & 0 & 0 & 0 & 0 & 0 & 0 & 0 & 0 & 102 & \multirow[t]{2}{*}{\begin{tabular}{l|l}
2 & 138
\end{tabular}} \\
\hline & & F & 34 & 0 & 0 & 1 & 0 & 1 & 0 & 0 & 0 & 0 & 0 & 0 & 0 & 0 & 0 & 36 & \\
\hline & \multirow{2}{*}{$\begin{array}{l}\text { Ringkse } \\
\mathrm{h}\end{array}$} & $\mathrm{M}$ & 63 & 4 & 5 & 0 & 1 & 0 & 0 & 0 & 0 & 0 & 0 & 0 & 0 & 0 & 0 & 73 & \multirow[t]{2}{*}{119} \\
\hline & & F & 42 & 0 & 4 & 0 & 0 & 0 & 0 & 0 & 0 & 0 & 0 & 0 & 0 & 0 & 0 & 46 & \\
\hline & \multirow[t]{2}{*}{ Total } & $\mathrm{M}$ & 160 & 4 & 6 & 1 & 1 & 3 & 0 & 0 & 0 & 0 & 0 & 0 & 0 & 0 & 0 & 175 & \multirow[t]{2}{*}{257} \\
\hline & & $\mathrm{F}$ & 76 & 0 & 4 & 1 & 0 & 1 & 0 & 0 & 0 & 0 & 0 & 0 & 0 & 0 & 0 & 82 & \\
\hline \multirow{3}{*}{\multicolumn{2}{|c|}{ Grand total }} & $\mathrm{M}$ & 302 & 4 & 8 & 1 & 1 & 3 & 2 & 5 & 3 & 1 & 104 & 0 & 1 & 3 & 1 & 439 & 587 \\
\hline & & $\mathrm{F}$ & 120 & 1 & 4 & 1 & 0 & 1 & 0 & 4 & 0 & 2 & 13 & 1 & 0 & 0 & 1 & 148 & \\
\hline & & $\begin{array}{l}\text { To } \\
\text { tal }\end{array}$ & 422 & 5 & 12 & 2 & 1 & 4 & 2 & 9 & 3 & 3 & 117 & 1 & 1 & 3 & 2 & 587 & \\
\hline
\end{tabular}

\section{Occupation:}

Status of a person is usually known by the occupation group he belongs to. The households were classified into different occupation categories according to the primary occupation (vide Table -7 ).

We have defined primary and secondary occupation on the basis of quantum of income generated from different sources. Primary occupation is that which gives more than half of the total when there are more than one occupation.

It is expected that people having more than one occupation have greater access to population. But at the same time because of their being in more than one occupation, they find less time to devote for the people than their counterparts having only one occupation. 
Table 7: Distribution of households by occupation

\begin{tabular}{|c|c|c|c|c|c|c|c|c|}
\hline 莺 & 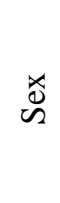 & 离 & 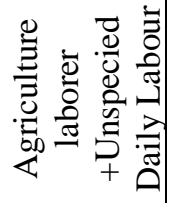 & 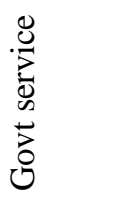 & 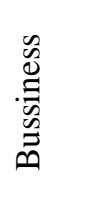 & $\begin{array}{l}\stackrel{0}{2} \\
\vdots \\
\vdots \\
0 \\
0 \\
0 \\
0 \\
01\end{array}$ & $\frac{\sqrt[n]{\Delta}}{\stackrel{0}{0}}$ & 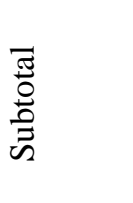 \\
\hline \multirow{2}{*}{ 节 } & $\frac{0}{\Sigma}$ & $\begin{array}{c}33 \\
(12.5)\end{array}$ & $\begin{array}{c}120 \\
(45.5)\end{array}$ & $\begin{array}{c}61 \\
(23.1)\end{array}$ & $\begin{array}{c}24 \\
(9.1)\end{array}$ & $\begin{array}{c}0 \\
(0.0)\end{array}$ & $\begin{array}{c}26 \\
(9.8)\end{array}$ & $\begin{array}{c}264 \\
(100.0)\end{array}$ \\
\hline & 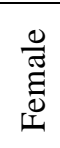 & $\begin{array}{c}8 \\
(12.12)\end{array}$ & $\begin{array}{c}10 \\
(15.15)\end{array}$ & $\begin{array}{c}5 \\
(7.58)\end{array}$ & $\begin{array}{c}2 \\
(3.03)\end{array}$ & $\begin{array}{c}30 \\
(45.45)\end{array}$ & $\begin{array}{c}11 \\
(16.07)\end{array}$ & $\begin{array}{c}66 \\
(100.00)\end{array}$ \\
\hline \multirow{2}{*}{$\begin{array}{l}\frac{\pi}{\vec{\pi}} \\
\frac{\pi}{000} \\
\sum_{\Sigma}^{\infty}\end{array}$} & $\frac{0}{\Sigma^{\pi}}$ & $\begin{array}{c}19 \\
(10.8)\end{array}$ & $\begin{array}{c}101 \\
(57.7)\end{array}$ & $\begin{array}{c}36 \\
(20.6)\end{array}$ & $\begin{array}{c}11 \\
(6.3)\end{array}$ & $\begin{array}{c}0 \\
(0.0)\end{array}$ & $\begin{array}{c}8 \\
(4.6)\end{array}$ & $\begin{array}{c}175 \\
(100.0)\end{array}$ \\
\hline & 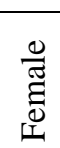 & $\begin{array}{c}1 \\
(1.22)\end{array}$ & $\begin{array}{c}41 \\
(50.00)\end{array}$ & $\begin{array}{c}12 \\
(14.63)\end{array}$ & 0 & $\begin{array}{c}17 \\
(20.73)\end{array}$ & $\begin{array}{c}11 \\
(13.41)\end{array}$ & $\begin{array}{c}82 \\
(100.00)\end{array}$ \\
\hline
\end{tabular}

Figures in parentheses give percentages.

\section{BPL/APL Status:}

$15 \%$ of the total female headed households in Tripura are in the BPL category whereas in Meghalaya it is almost $70 \%$. In total for Tripura it is observed that there is more female headed BPL families than male headed BPL's, but in Meghalaya it is almost same for the two sex.

Table 8: Distribution of households by BPL/APL status

\begin{tabular}{|l|l|l|l|l|}
\hline State & \multirow{2}{*}{ Sex } & Family Type & Subtotal \\
\cline { 3 - 5 } & & BPL & APL & \\
\hline Meghalaya & Male & $122(69.7)$ & $53(30.3)$ & $175(100.0)$ \\
\hline & Female & $57(69.5)$ & $25(30.5)$ & $82(100.0)$ \\
\hline Tripura & Male & $10(3.8)$ & $254(96.2)$ & $264(100.0)$ \\
\hline & Female & $10(15.5)$ & $56(84.5)$ & $66(100.0)$ \\
\hline
\end{tabular}

Figures in parentheses give percentages.

\section{Family Size}

Surprisingly there are many families in Meghalaya with size 8 or more. They are in most cases the joint families. In general, the family size is more in Meghalaya than that of Tripura.

Table 9 : Distribution of households by Family size

\begin{tabular}{|c|c|c|c|c|c|c|}
\hline \multirow{2}{*}{ State } & \multirow{2}{*}{ Sex } & \multicolumn{3}{|c|}{ Family Size } & Subtotal & $\begin{array}{c}\text { BPL } \\
\text { Percentage }\end{array}$ \\
\cline { 2 - 7 } & & $1-2$ & $3-7$ & $>7$ & & \\
\hline Meghalaya & Male & 28 & 106 & 41 & & 175 \\
\cline { 2 - 7 } & Female & $\mathbf{2 3}$ & $\mathbf{4 7}$ & $\mathbf{1 2}$ & & $\mathbf{8 2}$ \\
\hline \multirow{2}{*}{ Tripura } & Male & 104 & 156 & 4 & & 264 \\
\cline { 2 - 7 } & Female & $\mathbf{1 3}$ & $\mathbf{5 2}$ & $\mathbf{1}$ & & $\mathbf{6 6}$ \\
\hline
\end{tabular}

\section{Land Holdings}

We have taken the following classifications to see the distribution of land holdings.

Low-marginal land

Medium-marginal

High-Marginal

Small less than 3 bigha

land greater than 3 bigha but less than 6 bigha

land greater than 6 bigha but less than 7.5 bigha

land greater than 7.5 bigha but less than 15 bigha 
If we consider both the states then there are $52.30 \%$ landless households, $39.52 \%$ households have lowmarginal lands and $6.64 \%$ of total households have medium-marginal land and only $1.02 \%$ have high-marginal land holdings, but only $0.51 \%$ falls into the category of "small" land holdings.

In Meghalaya the size of the land holdings of the households are very small. They only have a lowmarginal land property (which is the homestead land) and some agricultural land, which fall in the marginal land group. But a worth mentioning feature is that in Ringkseh male headed households who are landless are more in number than their female counterpart.

Table 10: Distribution of the households by their land holdings

\begin{tabular}{|c|c|c|c|c|c|c|c|c|c|}
\hline \multirow[t]{3}{*}{ State } & \multirow[t]{3}{*}{ Village } & \multirow[t]{3}{*}{ Sex } & \multicolumn{5}{|c|}{ Land } & \multirow{3}{*}{ Subtotal } & \multirow[t]{3}{*}{ Total } \\
\hline & & & \multirow[b]{2}{*}{ 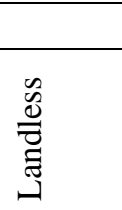 } & \multicolumn{3}{|c|}{ Marginal } & \multirow[b]{2}{*}{$\begin{array}{l}\overline{\tilde{\Xi}} \\
\text { है }\end{array}$} & & \\
\hline & & & & $\underline{z}$ & 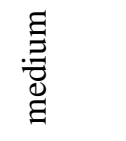 & $\stackrel{50}{.00}$ & & & \\
\hline \multirow[t]{6}{*}{ Tripura } & \multirow[t]{2}{*}{ Beltali } & Male & $\begin{array}{l}40 \\
(36.36)\end{array}$ & $\begin{array}{l}58 \\
(52.73)\end{array}$ & $\begin{array}{l}10 \\
(9.09)\end{array}$ & $\begin{array}{l}2 \\
(1.82)\end{array}$ & 0 & 110 & \multirow[t]{2}{*}{137} \\
\hline & & Female & $\begin{array}{l}14 \\
(51.85)\end{array}$ & $\begin{array}{l}11 \\
(40.74)\end{array}$ & $\begin{array}{l}1 \\
(3.70)\end{array}$ & $\begin{array}{l}1 \\
(3.70)\end{array}$ & 0 & 27 & \\
\hline & \multirow[t]{2}{*}{ Kalitila } & Male & $\begin{array}{l}59 \\
(38.31)\end{array}$ & $\begin{array}{l}83 \\
(53.90)\end{array}$ & $\begin{array}{l}7 \\
(4.55)\end{array}$ & $\begin{array}{l}3 \\
(1.95)\end{array}$ & $\begin{array}{l}2 \\
(1.30)\end{array}$ & 154 & \multirow[t]{2}{*}{193} \\
\hline & & female & $\begin{array}{l}13 \\
(33.33) \\
\end{array}$ & $\begin{array}{l}21 \\
(53.85) \\
\end{array}$ & $\begin{array}{l}4 \\
(10.26)\end{array}$ & & $\begin{array}{l}1 \\
(2.56) \\
\end{array}$ & 39 & \\
\hline & \multirow[t]{2}{*}{ Total } & Male & $\begin{array}{l}99 \\
(37.50)\end{array}$ & $\begin{array}{l}141 \\
(53.41)\end{array}$ & $\begin{array}{l}17 \\
(6.44)\end{array}$ & $\begin{array}{l}5 \\
(1.89)\end{array}$ & $\begin{array}{l}2 \\
(0.76)\end{array}$ & 264 & \multirow[t]{2}{*}{330} \\
\hline & & Female & $\begin{array}{l}27 \\
(40.91)\end{array}$ & $\begin{array}{l}32 \\
(48.48)\end{array}$ & $\begin{array}{l}5 \\
(7.58)\end{array}$ & $\begin{array}{l}1 \\
(1.52)\end{array}$ & $\begin{array}{l}1 \\
(1.52)\end{array}$ & 66 & \\
\hline \multirow[t]{6}{*}{ Meghalaya } & \multirow[t]{2}{*}{$\begin{array}{l}\text { Kynton- } \\
\text { o-Mon }\end{array}$} & Male & $\begin{array}{l}77 \\
(75.49)\end{array}$ & $\begin{array}{l}12 \\
(11.76)\end{array}$ & $\begin{array}{l}13 \\
(12.75)\end{array}$ & 0 & 0 & 102 & \multirow[t]{2}{*}{138} \\
\hline & & Female & $\begin{array}{l}29 \\
(80.56)\end{array}$ & $\begin{array}{l}6 \\
(16.67)\end{array}$ & $\begin{array}{l}1 \\
(2.78)\end{array}$ & 0 & 0 & 36 & \\
\hline & \multirow[t]{2}{*}{ Ringkseh } & Male & $\begin{array}{l}53 \\
(72.60)\end{array}$ & $\begin{array}{l}18 \\
(24.66)\end{array}$ & $\begin{array}{l}2 \\
(2.74)\end{array}$ & 0 & 0 & 73 & \multirow[t]{2}{*}{119} \\
\hline & & Female & $\begin{array}{l}22 \\
(47.83) \\
\end{array}$ & $\begin{array}{l}23 \\
(50.00) \\
\end{array}$ & $\begin{array}{l}1 \\
(2.17) \\
\end{array}$ & 0 & 0 & 46 & \\
\hline & \multirow[t]{2}{*}{ Total } & Male & $\begin{array}{l}130 \\
(74.29)\end{array}$ & $\begin{array}{l}30 \\
(17.14) \\
\end{array}$ & $\begin{array}{l}15 \\
(8.57) \\
\end{array}$ & 0 & 0 & 175 & \multirow[t]{2}{*}{257} \\
\hline & & Female & $\begin{array}{l}51 \\
(62.20)\end{array}$ & $\begin{array}{l}29 \\
(35.37)\end{array}$ & $\begin{array}{l}2 \\
(2.44)\end{array}$ & 0 & 0 & 82 & \\
\hline \multirow{3}{*}{\multicolumn{2}{|c|}{ Grand Total }} & male & $\begin{array}{l}229 \\
(52.16)\end{array}$ & $\begin{array}{l}171 \\
(38.95)\end{array}$ & $\begin{array}{l}32 \\
(7.29)\end{array}$ & $\begin{array}{l}5 \\
(1.14) \\
\end{array}$ & $\begin{array}{l}2 \\
(0.46) \\
\end{array}$ & 439 & \multirow[t]{2}{*}{587} \\
\hline & & Female & $\begin{array}{l}78 \\
(52.70)\end{array}$ & $\begin{array}{l}61 \\
(41.22)\end{array}$ & $\begin{array}{l}7 \\
(4.73) \\
\end{array}$ & $\begin{array}{l}1 \\
(0.68)\end{array}$ & $\begin{array}{l}1 \\
(0.68)\end{array}$ & 148 & \\
\hline & & Total & 307 & $\begin{array}{l}232 \\
(39.50)\end{array}$ & $\begin{array}{l}39 \\
(6.64)\end{array}$ & $\begin{array}{l}6 \\
(1.02)\end{array}$ & $\begin{array}{l}3 \\
(0.51)\end{array}$ & 587 & \\
\hline
\end{tabular}

\section{Concluding Remarks:}

(1) In Tripura the earner dependent ratio of the female heads is 1:1 (total) but in Meghalaya it is almost equal to 1:2 (total). The average family size in Meghalaya is also higher than that of Tripura.

(2) Among females there are $60.6 \%$ illiterates in Tripura and $63.4 \%$ illiterates in Meghalaya. The corresponding percentages for male heads are as $13.3 \%$ and $54.9 \%$ only.

(3) There is a large variation between the two states on the percentage of households in the BPL category. In Meghalaya there are about $70 \%$ households who belong to BPL category and there is not much difference between male headed and female-headed households. In Tripura, there are only 6\% BPL households. If we see it separately for male and female-headed households in Tripura, the percentages are 3.8 and 15.5 respectively. 
(4) The main dominating outside activity in Tripura is 'visiting Panchayat' irrespective of sex, though the proportion of female heads visiting Panchayat is much less for female headed households. In Meghalaya, percentages of participations of heads of households in outside activities are less than 10.

Above all these findings, point out to the fact that the females are dominated and get less privilege even in matrilineal societies. There is not much difference between a matrilineal and a patrilineal society so far as gender discrimination is concerned.

Literacy status, earning capacity, and participation in outside activities are less for females. There is thus a need for specific economic, social, agricultural and related policies in support of female-headed households.

\section{References:}

[1] Beteille. A., (1974), social Inequality, Harmondsworth, Penguin Books, New Delhi

[2] Chattopadhyay, R. and E. Duflo (2001): "Women as Policy Maker: Evidence from a India-wide Randomized Policy Experiment",

[3] Choksi, Armeane M. (1995): Forward in "Toward Gender Inequality: The Role of Public Policy", World Bank Publications, Washington D.C., USA, p. viii.

[4] Devendra, Kiran (1993): "Sex Discrimination: Before and Birth", in Girl Child and Family Violence, ed. Pramila Kapur, New Delhi, Har Anand Publications.

[5] Ghosh, B \& U.K. De(2002), "Leadership and the performance of panchayats in Rural Development: An Experience from Tripura " paper presented at the UGC national seminar on ' Transformation in Rural Society', held at Tufanjang Mahavidyalaya, West Bengal, on 24-25 September, 2002.

[6] Hamilton, Cicely (1981), Marriage as a trade, Women's press London.

[7] Madhu Kishwar (1996): in Munshi, http://www.freespeech.org/manushi/ 96/zenana.html.

[8] Menon, L.D. (1975), "India and International Women's Year", India Quarterly, Vol. 31. No. 3, July- Sept., p. 278.

[9] Schreiner, Olive (1978) Women and Labour, Virago, London, p.1.

[10] Thomas P. (1964), Indian Women through The Age, Asia Publishing house, Bombay, p.49

[11] World Bank (1995): "Toward Gender Inequality: The Role of Public Policy", World Bank Publications, Washington D.C., USA, p. 2 . 